\title{
KONDISI MAKRO EKONOMI TERHADAP HASIL INVESTASI ASURANSI JIWA SYARIAH DI [NDONESIA ${ }^{1]}$
}

Firsty Dzanurrahmana Zein

Studi Ekonomi Islam-Fakultas ekonomin dan Bisnis-Universitas Airlangga

Email: firsty.dzanurrahmana-12@feb.unair.ac.id

\author{
Atina Shofawati \\ Departemen Ekonomi Syariah-Fakultas Ekonomi dan Bisnis-Universitas Airlangga \\ Email: atina-o@feb.unair.ac.id
}

\begin{abstract}
:
This research attempt to analyze the effect of variable inflation, Rupiah exchange rate, and gross domestic product towards investment result of sharia life insurance in Indonesia period 2012:Q1 until 2016:Q1. This research using quantitative methods. The analysis techniques used is multiple linear regression with data panel and significance level of 0,05. The approach used in this research is Random Effect Model. The result of t-test, gross domestic bruto has a significant influence to investment result of sharia life insurance with 0,0459. Inflation and Rupiah exchange rate has not significant influence to investment result of sharia life insurance. However, inflation, Rupiah exchange rate and gross domestic product simultaneously provide a significant effect to Investment result of sharia life insurance.
\end{abstract}

\section{Keywords: Inflation, Rupiah Exchange Rate, Gross Domestic Product, Investment Result,} Sharia Life Insurance.

\section{PENDAHULUAN}

Perusahaan asuransi jiwa syariah tumbuh berkembang seiring dengan menggeliatnya lembaga keuangan berbasis syariah. Menurut data Asosiasi Asuransi Syariah Indonesia kini jumlah industri asuransi jiwa syariah sebanyak 24 perusahaan. Perolehan hasil investasi asuransi jiwa syariah di Indonesia sampai tahun 2015 menunjukkan peningkatan yang cukup signifikan yaitu sebesar 19,72\%

Pengembangan asuransi jiwa syariah diperlukan sejumlah indikator untuk meyakinkan para investor bahwa asuransi jiwa syariah di Indonesia mempunyai prospek yang sangat baik karena masih terbukanya peluang pasar asuransi jiwa 1) Jurnal ini merupakan bagian dari skripsi yang 041211432117 yang diuji pada 14 Desember 2015

dibandingkan dengan tahun sebelumnya. Total hasil investasi asuransi jiwa syariah sebesar Rp 19.576 miliar. Namun secara makro, hasil investasi asuransi jiwa syariah hanya sebesar $5,6 \%$ dari total investasi asuransi nasional. Penduduk Indonesia dengan mayoritas muslim diperkirakan bahwa peran asuransi jiwa syariah di Indonesia dapat menyumbang terhadap target perolehan investasi nasional sekeurang-kurangnya $\quad 10 \% \quad$ (Majalah Ekonomi, 2015).

syariah dan beberapa indikator lainnya yang menjadi acuan kegiatan operasional perusahaan memberikan daya tarik untuk dibukanya industri asuransi jiwa syariah (Soedibjo dan Fitriati, 2009). Menurut data ekonomi makro yang telah diolah, bahwa ditulis oleh Firsty Dzanurrahmana Zein, NIM: 
potensi pasar asuransi jiwa di Indonesia: (lihat tabel 1)

Jumlah investasi asuransi jiwa di indonesia berjumlah 283,196 miliar atau sekitar $81 \%$ dari total investasi seluruh asuransi. Hal ini menunjukkan bahwa perkembangan usaha seluruh asuransi jiwa dalam industri perasuransian lebih dominan dari pada asuransi umum, sedangkan, sumbangan sektor asuransi jiwa syariah terhadap PDB kurang dari 1\% yaitu baru sekitar $0,22 \%$ terhadap PDB tahun 2015. Ini berarti masih terbuka peluang untuk meningkatkan hasil investasi asuransi jiwa syariah di masa datang. Peningkatan hasil investasi berdasarkan pada pendapatan premi takaful karena sebelum memperoleh hasil investasi perusahaan terlebih dahulu harus mengelola dana peserta dengan akad wakalah bil ujrah. Peningkatan besar kontribusi takaful dipengaruhi oleh iklim perekonomian nasional yang baik dan juga meningkatkan pendapatan per kapita penduduk dan peranan industri asuransi dalam memobilisasi dana masyarakat untuk bersaing dengan industri keuangan lainnya.

Pada perusahaan asuransi syariah memiliki hubungan kerjasama antar kedua belah pihak dengan melakukan transaksinya berdasarkan prinsip mudharabah yang bertujuan untuk melindungi tertanggung dari resiko keuangan masa depan yang tidak terduga. Perusahaan hanya sebagai pengelola dana atau mudharib, sedangkan pemegang polis atau peserta takaful sebagai shahibul maal yang merupakan pemilik dana sepenuhnya (Billah, 1998).

Prinsip asuransi syariah harus mampu menciptakan maqashid syariah, membangun moral, dan menetapkan bahwa uang bukan komoditas transaksi yang dijalankan secara bebas, termasuk pengelolaan dana dalam berinvestasi. Investasi yang dilakukan perusahaan tidak boleh mengandung unsur gharar (penipuan), maysir (perjudian), riba, barang haram dan tidak menempatkan dana pada lembaga keuangan yang berbasis bunga, atau pembelian saham perusahaan yang memperjualbelikan komoditi haram secara syariah (Anshory, 2007); (Antonio, 2004 dan Sula, 2004). Pembagian keuntungan investasi dana didasarkan pada akad yang disepakati dengan peserta yaitu dasar akad mudharabah (Karim 2001). 
Tabel 1 Indikator Ekonomi Makro Terhadap Pertumbuhan Asuransi Syariah di Indonesia Berdasarkan Inflasi, Nilai Tukar dan PDB

\begin{tabular}{|c|c|c|c|c|c|c|c|c|c|c|c|}
\hline \multirow{2}{*}{ No. } & \multirow{2}{*}{ Keterangan } & \multirow{2}{*}{2014} & \multirow{2}{*}{2015} & \multirow{2}{*}{ No. } & \multirow{2}{*}{ Keterangan } & \multicolumn{2}{|c|}{ Aset } & \multicolumn{2}{|c|}{ Investasi } & \multicolumn{2}{|c|}{ Premi Bruto } \\
\hline & & & & & & 2014 & 2015 & 2014 & 2015 & 2014 & 2015 \\
\hline \multirow{3}{*}{1} & \multirow{3}{*}{ Inflasi (\%) } & \multirow{3}{*}{8,36} & \multirow{3}{*}{3,35} & \multirow{3}{*}{1} & Seluruh Asuransi Jiwa & 323,15 & 329,68 & 278,61 & 283,196 & 121,62 & 102,42 \\
\hline & & & & & Asuransi Jiwa Syariah & 18,05 & 21,61 & 16,35 & 19,58 & 7,88 & 8,81 \\
\hline & & & & & Presentase Asuransi Jiwa Syariah & $5,29 \%$ & $6,15 \%$ & $5.54 \%$ & $6,47 \%$ & $6,48 \%$ & $8,60 \%$ \\
\hline \multirow{3}{*}{2} & Nilai Tukar & \multirow{3}{*}{12.502} & \multirow{3}{*}{13.864} & \multirow{3}{*}{2} & Seluruh Asuransi Kerugian dan Reasuransi & 117,68 & 132,56 & 59,91 & 66,147 & 55,17 & 57,61 \\
\hline & (dalam Ribu & & & & Asuransi Kerugian dan Reasuransi Syariah & 4,31 & 4,91 & 3,10 & 3,49 & 1,40 & 1,68 \\
\hline & Rupiah) & & & & Presentase Asuransi Umum S yariah & $3,54 \%$ & $3,57 \%$ & $4,93 \%$ & $5,02 \%$ & $2,54 \%$ & $2,91 \%$ \\
\hline \multirow{3}{*}{3} & PDB & \multirow{3}{*}{ 8.566.271,2 } & \multirow{3}{*}{$8.976 .931,5$} & \multirow{3}{*}{3} & Seluruh Asuransi & 440,83 & 462,241 & $\mathbf{3 3 8 , 5 3}$ & $\mathbf{3 4 9 , 3 4}$ & 176,80 & 160,03 \\
\hline & (dalam & & & & Seluruh Asuransi Syariah & 22,36 & 26,52 & 19,46 & 23,07 & 9,28 & 10,49 \\
\hline & $\begin{array}{l}\text { Minar } \\
\text { Rupiah) }\end{array}$ & & & & Presentase Seluruh Asuransi Syariah & $4,83 \%$ & $5,43 \%$ & $\mathbf{5 , 4 4 \%}$ & $6,19 \%$ & $5,25 \%$ & $6,55 \%$ \\
\hline
\end{tabular}

Sumber: Asosiasi Asuransi Syariah Indonesia, Bank Indonesia dan BPS 2015, data diolah.

Peraturan Menteri Keuangan Nomor 11/ PMK. 010/2011 tentang Kesehatan Keuangan Usaha Asuransi Dan Usaha Reasuransi Dengan Prinsip Syariah, berisi tentang kekayaan yang diperkenankan dalam bentuk investasi terdiri dari: deposito pada Bank, saham syariah, sukuk atau obligasi syariah, Surat Berharga Syariah Negara (SBSN), surat berharga syariah yang diterbitkan oleh Bank Indonesia, surat berharga syariah yang diterbitkan oleh lembaga multinasional yang Negara Republik Indonesia menjadi salah satu anggota atau pemegang sahamnya, reksadana syariah, efek beragun aset syariah yang diterbitkan berdasarkan kontrak investasi kolektif efek beragun aset syariah, pembiayaan melalui mekanisme kerjasama dengan pihak lain dalam bentuk pembelian pembiayaan (refinancing) syariah, dan/ atau emas murni. Kini, terdapat lima jenis investasi terbesar yang menjadi pilihan perusahaan asuransi jiwa syariah untuk berinvestasi, antara lain: deposito syariah, saham syariah, reksadana syariah, sukuk, dan Surat Berharga Syariah Negara (SBSN) (OJK, 2015).

Menurut Fahmi (2012: 36), pemilihan investasi sangat berpengaruh terhadap hasil investasi perusahaan, seperti yang dilakukan oleh manajer investasi yang bertugas menempatkan dana investasi ke beberapa portofolio investasi yang dapat memberikan return yang besar dengan tingkat resiko yang kecil. Hasil investasi pada perusahaan tidak luput dari beberapa faktor yang mempengaruhinya, antara lain tingkat inflasi, nilai tukar mata vang, dan perekonomian negara (Chen, Roll dan Ross, 1986).

Inflasi adalah proses kenaikan harga-harga barang secara terus menerus, yang berakibat menurunnya daya beli masyarakat karena secara riil tingkat pendapatan juga menurun (Putang, 2002:185). Fluktuasi nilai tukar rupiah terhadap mata vang asing yang stabil akan sangat mempengaruhi iklim investasi dalam negeri (Suta, 2000). Dan 
Zein, et al/Jurnal Ekonomi Syariah Teori dan Terapan Vol. 4 No. 10 Oktober 2017: 773-786; KONDISI MAKRO EKONOMI TERHADAP HASIL INVESTASI ASURANSI JIWA SYARIAH DI INDONESIA

PDB menunjukkan nilai seluruh output atau produk dalam perekonomian dalam negara tersebut atau nilai pasar semua barang dan jasa pada akhir produksi dalam perekonomian dalam kurun waktu tertentu biasanya satu tahun dengan menjumlahkan semua hasil dari warga negara yang bersangkutan ditambah warga negara asing yang bekerja di negara yang bersangkutan (Sukirno, 2002).

\section{LANDASAN TEORI}

\section{TEORI INVESTASI DARI SISI EKONOMI ISLAM}

Allah SWT. berfirman dalam surat alHasyr ayat 18

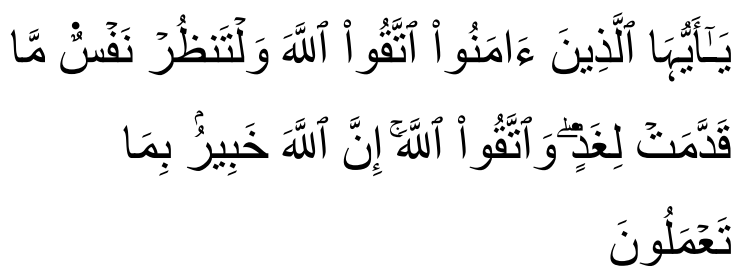

"Yā ai-yuhā'l-lażīna āmanūl-Lāha waltanz̧ur nafsun mā qadda mat ligadin wat-taqu'l-Lāha inna'l-Lāha khabīrun bimā ta'lamūn(a).

Artinya, "Hai orang-orang yang beriman, bertakwalah kepada allah dan hendaklah setiap diri memerhatikan apa yang telah diperbuatnya untuk hari esok (akhirat) dan bertakwalah kepada Allah, sesungguhnya Allah Maha Mengetahui apa yang kamu kerjakan."

Allah SWT. memerintahkan kepada seluruh umat-Nya yang beriman untuk melakukan investasi akhir dengan melakukan amal shaleh sejak dini sebagai bekal untuk menghadapi hari perhitungan (Huda dan Mustafa, 2008:18).

Menurut Metwally (1995:75), suatu fungsi investasi dalam perekonomian Islami dengan mengasumsikan tingkat suku bunga bernilai nol, dan mengganti variabel suku bunga dengan variabel expected rate of profit ( $r$ ) yang ditentukan oleh karakteristik bisnis pengusaha karena variabel tingkat suku bunga hanya ditentukan oleh pasar kredit (credit market).

Asumsi lain yang digunakan adalah: (1) terdapat sanksi terhadap pemegang aset yang kurang atau tidak produktif (idle assets), (2) dilarang melakukan berbagai bentuk spekulasi dan tindakan perjudian, (3) tingkat suku bunga pada semua jenis dana pinjaman adalah nol. Fungsi investasi dalam ekonomi Islam yang diperkenalkan oleh Metwally (1995:80) sebagai berikut:

$I=f(r, \mu)$

Keterangan:

I = Permintaan akan investasi

$r=$ Tingkat keuntungan yang diharapkan

$\mu=$ Pengelvaran lain-lain zakat atas aset yang tidak atau kurang produktif.

Faktor yang mempengaruhi besar kecilnya investasi dalam perekonomian Islami adalah (Metwally, 1995): (1) tingkat keuntungan yang diharapkan, pengelvaran lain-lain zakat atas aset yang tidak atau kurang produktif. 
Zein, et al/Jurnal Ekonomi Syariah Teori dan Terapan Vol. 4 No. 10 Oktober 2017: 773-786; KONDISI MAKRO EKONOMI TERHADAP HASIL INVESTASI ASURANSI JIWA SYARIAH DI INDONESIA

HASIL INVESTASI

Hasil investasi diperoleh dari penjumlahan akun pendapatan pengelolaan portofolio investasi dana peserta yang merupakan hasil penanaman modal dengan melakukan diversifikasi portofolio untuk mendapatkan perolehan bagi hasil optimum yang dananya berasal dari rekening peserta dan pendapatan investasi merupakan dana perusahaan yang diinvestasikan melalui diversifikasi portofolio untuk mendapatkan perolehan bagi hasil yang optimum dan menjadi hak perusahaan (Tolefat dan Mehmet, 2013:230-231). Kedua hasil investasi ini dapat diperoleh infonya pada laporan laba rugi dan penghasilan komprehensif lain dana perusahaan yang dipublikasikan.

Dana yang diinvestasikan perusahaan berasal dari kumpulan dana peserta yang sudah dibagi ke dalam dua rekening, yaitu rekening peserta dan rekening khusus peserta secara proporsional, yang kemudian diinvestasikan pada deposito syariah, saham syariah, sukuk/obligasi syariah, reksadana syariah, dan surat berharga syariah negara dengan ketentuan tertentu. Peraturan yang mengatur tempat investasi beserta porsinya adalah Keputusan Menteri Keuangan RI No. 424/KMK.06/2003 tentang Kesehatan Keuangan Perusahaan Asuransi dan Reasuransi yang mengatur pembatasan investasi pada perusahaan asuransi dan reasuransi dengan sistem syariah.

\section{INFLASI}

Menurut Mankiw (2005:164), inflasi adalah peningkatan seluruh tingkat harga, kadang-kadang kenaikan harga ini berlangsung terus-menerus dan meluas atau menyebabkan kenaikan pada barang lainnya. Inflasi merupakan fenomena moneter yang terjadi dimanapun. Sedangkan menurut Teori inflasi konvensional dalam Karim (2007:135136) adalah kenaikan secara menyeluruh jumlah vang yang harus dibayarkan (nilai unit penghitungan moneter) terhadap barang/komoditas dan jasa. Inflasi dapat diukur dengan tingkat inflasi (rate of inflation), yaitu tingkat perubahan dari tingkat harga secara umum.

Inflasi memiliki dampak positif dan dampak negatif berdasarkan seberapa besar perubahannya. Dampak dari inflasi yang rendah dan terkendali akan mempengaruhi pelaku usaha untuk melakukan investasi, namun dampak dari inflasi yang tinggi akan mengurangi tingkat pendapatan riil yang diperoleh investor dari investasinya (Alhasymi, 2010:2).

Inflasi yang semakin tinggi akan menurunkan pendapatan perusahaan. Pengelolaan dana tabarru' selalu diikuti dengan besar klaim peserta dan beban pengelolaan asuransi. Apabila klaim peserta ditambah beban pengelolaan asuransi lebih besar daripada pendapatan asuransi atau dalam kondisi defisit underwriting dana tabarru', maka akan mempengaruhi pendapatan 
perusahaan. Jika pendapatan turun, maka turunlah pula kepercayaan peserta terhadap perusahaan karena bagi hasil yang diterima lebih sedikit dari kondisi sebelumnya. Kondisi ini akan mengurangi hasil investasi asuransi jiwa syariah karena sedikitnya dana yang dikelola dalam portofolio investasi akibat berkurangnya peserta takaful dari jumlah sebelumnya, selain itu inflasi yang tinggi akan meningkatkan resiko dalam proyek investasi yang dilakukan oleh perusahaan asuransi jiwa syariah.

\section{NILAI TUKAR}

Menurut Sukirno (2002:237), nilai tukar adalah suatu nilai yang menunjukkan jumlah nilai mata uang dalam negeri yang diperlukan untuk mendapatkan satu unit mata vang asing. Sedangkan menurut Nopirin (1997:185), nilai tukar merupakan harga pertukaran anatar dua mata vang yang berbeda dengan perbandingan nilai/harga tertentu.

Dampak perubahan nilai tukar dengan investasi secara teoritis bersifat uncertainty (tidak pasti). Penurunan tingkat nilai tukar rupiah dalam jangka pendek akan mengurangi investasi absorsi domestik. Nilai tukar rupiah yang menguat akan menyebabkan kenaikan tingkat harga-harga secara umum dan selanjutnya menurunkan permintaan domestik masyarakat, sehingga perusahaan akan menurunkan alokasi modal pada investasi (Alhasymi, 2010:3).
PRODUK DOMESTIK BRUTO

PDB merupakan nilai seluruh output atau produk dalam perekonomian dalam negara tersebut atau nilai pasar semua barang dan jasa pada akhir produksi dalam perekonomian dalam kurun waktu satu tahun dengan menjumlahkan semua hasil dari warga negara yang bersangkutan ditambah warga negara asing yang bekerja di negara yang bersangkutan (Sukirno, 2002:93).

Menurut Zuhra (2015), PDB menjadi salah satu indikator atau alat ukur pertumbuhan ekonomi suatu negara karena dapat mengetahui gambaran kondisi ekonomi suatu negara dalam suatu periode tertentu. Hasil investasi akan terpacu oleh kondisi perekonomian yang baik sebab kondisi perekonomian direfleksikan dalam bentuk pertumbuhan PDB. Perubahan PDB berbanding lurus dengan hasil investasi. Ketika PDB menurun menunjukkan bahwa perekonomian sedang mengalami penurunan yangberakibat hasil investasi mengalami penurunan, sebaliknya jika PDB meningkat maka dapat memacu aktivitas investasi negara tersebut termasuk aktivitas investasi pada asuransi jiwa syariah maupun perusahaan bertindak sebagai investor untuk berinvestasi.

\section{MODEL ANALISIS}

Penelitian ini menggunakan analisis dengan kerangka kerja penelitian untuk menjelaskan hubungan antara variabel 
independen dan variabel dependen. Model analisis penelitian ini adalah:

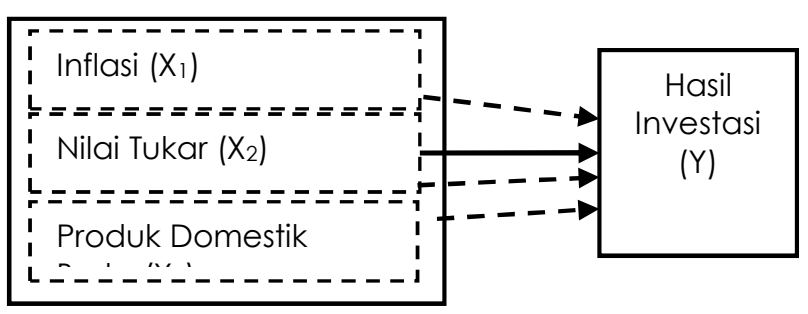

Keterangan: : hubungan simultan

$$
\text { -.-.-.-: hubungan parsial }
$$

Sumber: Diolah dari berbagai sumber

\section{Gambar 1. Model Analisis}

\section{METODE PENELITIAN}

Penelitian dengan pendekatan kuantitaif ini menggunakan teknik analisis regresi berganda data panel. Data panel merupakan gabungan antara data time series dengan data cross section. Data time series yaitu data yang berupa nilai dari satu atau lebih variabel selama satu periode. Data cross section yaitu nilai dari satu atau lebih, variabel yang diambil dari beberapa unit sampel dalam periode waktu yang sama (Gujarati, 2013: 235).

\section{IDENTIFIKASI VARIABEL}

Variabel yang digunakan dalam penelitian ini adalah variabel dependen dan variabel independen. Variabel dependen (terikat) adalah variabel yang dipengaruhi atau menjadi akibat karena adanya variabel bebas, sedangkan variabel independen (bebas) adalah variabel yang mempengaruhi atau menjadi sebab perubahannya atau timbulnya variabel dependen (Soegiyono, 2003). Variabel terikat yang digunakan dalam penelitian ini adalah hasil investasi pada perusahaan asuransi jiwa syariah di Indonesia, sedangkan variabel independen dalam penelitian ini antara lain inflasi, nilai tukar, dan PDB.

Bentuk persamaan regresi liniear berganda dapat dirumuskan sebagai berikut :

$Y=\alpha+\beta_{1} \chi_{1}+\beta_{2} \chi_{2}+\beta_{3} \chi_{3}+\varepsilon$ Keterangan:

$$
\begin{array}{lll}
\mathrm{Y} & =\text { Variabel Hasil Investasi } \\
\mathrm{X}_{1} & =\text { Variabel Inflasi } \\
\mathrm{X}_{2} & =\text { Variabel Nilai Tukar } \\
\mathrm{X}_{3} & =\text { Variabel Produk Domestik } \\
& \text { Bruto } \\
\alpha & =\text { Intercept } \\
\mathrm{e} & =\text { Kesalahan pengganggu } \\
\beta_{1}, \beta_{2}, \beta_{3}= & \text { Koefisien Regresi }
\end{array}
$$

\section{DEFINISI OPERASIONAL}

\section{Inflasi}

Inflasi adalah meningkatnya hargaharga secara umum dan terus menerus. Indikator yang digunakan untuk mengukur tingkat inflasi adalah Indeks Harga Konsumen (IHK). Data variabel inflasi yang digunakan adalah indeks harga konsumen nasional yang dikeluarkan oleh Bank Indonesia (BI) secara triwulanan/ setiap akhir bulan Maret, Juni, September dan Desember selama periode 2012:Q12016:Q1. 


\section{Nilai tukar}

Nilai tukar rupiah adalah harga mata vang suatu negera terhadap mata vang Negara lain (Pilbeam, 2006:72). Data nilai tukar merupakan data nilai kurs tengah Rupiah terhadap Dollar Amerika yang diperoleh dari Bank Indonesia (BI) secara triwulanan/ setiap akhir bulan Maret, Juni, September dan Desember selama periode 2012:Q1-2016:Q1.

\section{Produk Domestik Bruto (PDB)}

Produk Domestik Bruto merupakan nilai seluruh output atau produk dalam perekonomian suatu negara (Sukirno, 2002:93). Produk Domestik Bruto (PDB) yang digunakan pada penelitian ini adalah PDB dengan pendekatan pengeluaran dengan harga konstan secara triwulanan/ setiap akhir bulan Maret, Juni, September dan Desember selama periode 2012:Q1-2016:Q1 yang dikeluarkan oleh Badan Pusat Statistik (BPS).

\section{Variabel Terikat $(Y)$}

Hasil investasi perusahaan asuransi syariah diperoleh dari penjumlahan pendapatan pengelolaan portofolio investasi dana peserta dengan pendapatan investasi yang modalnya berasal dari dana perusahaan kemudian diinvestasikan berupa portofolio (Tolefat dan Mehmet, 2013:230-231). Pada penelitian ini hasil investasi diperoleh infonya pada laporan laba rugi dan penghasilan komprehensif lain dana perusahaan yang dipublikasikan dalam website resmi masing-masing asuransi jiwa syariah di Indonesia secara triwulanan/ setiap akhir bulan Maret, Juni, September dan Desember selama periode penelitian 2012:Q1-2016:Q1.

\section{JENIS DAN SUMBER DATA}

Data yang digunakan pada penelitian ini adalah data sekunder. Data dari variabel hasil investasi yang digunakan di dalam penelitian ini menggunakan data publikasi yang diterbitkan dari website resmi perusahaan asuransi jiwa syariah di Indonesia, sedangkan data dari variabel inflasi dan nilai tukar website resmi Bank Indonesia, dan data dari variabel PDB website resmi Badan Pusat Statistik dengan urutan waktu yang digunakan dalam penelitian ini dimulai dari periode 2012:Q1-2016:Q1.

\section{POPULASI DAN SAMPEL}

Populasi dalam penelitian ini adalah seluruh perusahaan asuransi jiwa syariah yang ada di Indonesia baik yang umum maupun yang masih berupa unit usaha syariah pada periode 2012:Q12016:Q1 dan terdapat 24 asuransi jiwa syariah. Teknik pengambilan sampel dengan teknik purposive sampling dengan tujuan untuk mendapatkan sampel yang representatif sesuai dengan kriteria yang telah ditentukan (Anshori dan Iswati, 2009:105). Sampel yang digunakan dalam penelitian ini sebanyak empat perusahaan asuransi jiwa syariah dalam periode waktu penelitian 2012 : Q1 - 2016 : Q1 sehingga terdapat 68 observasi. 
Kriteria sampel pada penelitian ini sebagai berikut:

1. Perusahaan asuransi jiwa syariah maupun asuransi jiwa unit syariah yang selalu menyajikan atau menerbitkan secara terus menerus dan menyampaikan data laporan kevangan secara lengkap yang berkaitan dengan variabel penelitian selama periode 2012: Q1 - 2016: Q1.

2. Perusahaan asuransi jiwa syariah yang terdaftar di Direktori Perasuransian yang diterbitkan oleh statistik perasuransian OJK.

3. Perusahaan asuransi yang masih beroperasi secara syariah pada awal tahun 2012 hingga tahun 2016 quartal pertama.

Sampel yang memenuhi semua kriteria tersebut yaitu PT. Asuransi Jiwa AlAmin, PT. Avrist Assurance Unit Syariah, PT. Panin Daichi Life Unit Syariah, PT. Asuransi Jiwa Mega Life.

\section{HASIL DAN PEMBAHASAN}

Uji pemilihan model yang pertama adalah uji Chow atau uji F-statistik untuk memilih pendekatan yang terbaik antara Pooled Least Square (PLS) dan Fixed Effect Model (FEM). Pengujian ini dilakukan dengan hipotesis sebagai berikut: $\mathrm{H}_{0}=$ Pooled Least Square (PLS) dan $\mathrm{H}_{1}=$ Fixed Effect Model (FEM). Pengujian ini memiliki kriteria pengambilan keputusan sebagai berikut: Jika nilai signifikan lebih kecil dari 0,05 maka hipotesis Ho ditolak berarti model yang digunakan adalah model
FEM. Dan jika nilai signifikan lebih besar dari 0,05 maka hipotesis $\mathrm{H}_{0}$ diterima berarti model yang digunakan adalah model PLS.

Tabel 2 Hasil Uji Chow/F-statistik

\begin{tabular}{|c|c|c|c|}
\hline Effect Test & Statistic & d.f. & Prob. \\
\hline Cross-section F & 44.882679 & $(3,61)$ & 0.0000 \\
\hline
\end{tabular}

Sumber: Data diolah

Berdasarkan tabel 2, hasil penelitian dengan menggunakan Eviews7 diketahui bahwa nilai probabilitasnya $\mathrm{F}<$ 0,05. Hal ini menunjukkan bahwa $\mathrm{H}_{0}$ yang menyatakan model Pooled Least Square (PLS) ditolak sehingga model regresi data panel yang lebih baik digunakan adalah Fixed Effect Model (FEM).

Pengujian berikutnya adalah uji Hausman, uji ini digunakan untuk memilih model mana yang lebih baik antara Fixed Effect Model (FEM) dan Random Effect Model (REM). Pengujian ini dilakukan dengan hipotesis sebagai berikut: $\mathrm{H}_{0}=$ Random Effect Model (REM) dan $\mathrm{H}_{1}=$ Fixed Effect Model (FEM). Kriteria pengambilan keputusan pengujian ini sebagai berikut: Jika nilai signifikan lebih kecil dari 0,05 maka hipotesis $\mathrm{H}_{0}$ ditolak berarti model yang digunakan adalah model FEM. Dan jika nilai signifikan lebih besar dari 0,05 maka hipotesis $\mathrm{H}_{0}$ diterima berarti model yang digunakan adalah model REM. 
Tabel 3 Hasil Uji Hausman

\begin{tabular}{|c|c|c|c|}
\hline $\begin{array}{c}\text { Test } \\
\text { Summary }\end{array}$ & $\begin{array}{c}\text { Chi-Sq. } \\
\text { Statistic }\end{array}$ & $\begin{array}{c}\text { Chi-Sq. } \\
\text { d.f }\end{array}$ & Prob. \\
\hline $\begin{array}{c}\text { Cross-section } \\
\text { random }\end{array}$ & 0,000000 & 3 & 1,0000 \\
\hline
\end{tabular}

Sumber: Data diolah

Berdasarkan hasil tabel 3 uji Hausman yang telah dilakukan bahwa nilai Chi-Squares sebesar 0,000000 dengan nilai probabilitas model penelitian ini lebih besar dari 0,05 yang artinya $\mathrm{H}_{0}$ diterima sehingga teknik estimasi yang dipilih adalah Random Effect Model (REM).

Identifikasi hasil estimasi persamaan regresi data panel dalam penelitian ini dimaksudkan untuk mengetahui pengaruh variabel inflasi, nilai tukar, dan produk domestik bruto terhadap hasil investasi perusahaan asuransi jiwa syariah periode 2012:1-2016:1. Hasil estimasi persamaan regresi data panel model Random Effect Model (REM) dapat dilihat pada tabel 4.

\section{Tabel 4 Hasil Regresi Data Panel Model REM}

\begin{tabular}{l|c|c|c|c|}
\hline Variable & Coefficient & Std. Error & t-Statistic & Prob. \\
\hline INF & 0.035878 & 0.057996 & 0.618630 & 0.5384 \\
\hline LOG(KURS) & -1.280 .945 & 2.059 .133 & -0.622080 & 0,5361 \\
\hline LOG(PDB) & 9.486 .806 & 4.660 .204 & 2.035 .706 & 0,0459 \\
\hline C & -3.011 .785 & 1.462 .188 & $-2,05978$ & 0.0435 \\
\hline & & & & \\
\hline \multicolumn{4}{|c|}{ Effect Specification } \\
\hline \multicolumn{4}{|c|}{ Cross-Section fixed (dummy variables) } \\
\hline R-squared & 0,297068 \\
\hline Adju sted R-squared & 0,264118 \\
\hline F-Statistic & 9,015719 \\
\hline Prob (F-Statistic) & 0,000046 \\
\hline Durbin-Watson Statistic & 1,309481 \\
\hline
\end{tabular}

Hasil pembuktian regresi dari data panel dengan model REM pada variabel bebas yaitu inflasi, nilai tukar, dan PDB terhadap variabel terikat yaitu hasil investasi dilakukan dengan uji t-statistik dengan melihat nilai probabilitas sesuai dengan tingkat derajat keyakinan $\alpha$ yang telah ditetapkan yaitu 0,1 atau $10 \%$. Setiap variabel bebas dilakukan uji tstatistik untuk melihat pengaruh terhadap variabel terikat, sedangkan untuk penilaian secara serentak antara variabel bebas terhadap variabel terikat melalui probabilitas statistik uji F. Hal di atas dapat dibuat sebuah model analisis persamaan dari regresi berganda sebagai berikut:

\section{$Y=-301.1785+0.035878 X_{1}-1.280945 X_{2}+$ \\ $9.486806 X_{3}$}

\section{Uji Signifikansi Parsial ( Uji t)}

Pembuktian hipotesis menggunakan uji $\dagger$ karena uji $\dagger$ memiliki fungsi sebagai analisis tingkat signifikan pengaruh variabel bebas terhadap variabel terikat secara parsial. Berdasarkan hasil analisis penghitungan regresi data panel dengan menggunakan model REM dapat disimpulkan bahwa:

1. Nilai probabilitas inflasi sebesar 0.5384 lebih besar dari 0,1 maka dapat disimpulkan bahwa variabel inflasi tidak berpengaruh signifikan terhadap hasil investasi.

2. Nilai probabilitas kurs sebesar 0.5361 lebih besar dari 0,1 maka dapat disimpulkan bahwa variabel nilai tukar 
Zein, et al/Jurnal Ekonomi Syariah Teori dan Terapan Vol. 4 No. 10 Oktober 2017: 773-786; KONDISI MAKRO EKONOMI TERHADAP HASIL INVESTASI ASURANSI JIWA SYARIAH DI INDONESIA

tidak berpengaruh signifikan terhadap hasil investasi.

3. Nilai probabilitas PDB sebesar 0.0459 lebih kecil dari 0,1 maka dapat disimpulkan bahwa variabel PDB berpengaruh signifikan terhadap hasil investasi.

\section{Uji Signifikansi Simultan (Uji F)}

Inflasi, nilai tukar dan Produk Domestik Bruto (PDB) mempunyai nilai probabilitas lebih kecil dari $\alpha=0,1$ yaitu sebesar 0,000046, sehingga dapat disimpulkan bahwa inflasi, nilai tukar dan PDB secara simultan berpengaruh signifikan terhadap hasil investasi perusahaan asuransi jiwa syariah di Indonesia. Maka dari itu, beberapa indikator dari ekonomi makro antara lain inflasi, nilai tukar, dan Produk Domestik Bruto (PDB) memiliki peran yang penting dalam menentukan besar kecilnya hasil investasi yang dilakukan oleh perusahaan asuransi jiwa syariah.

\section{Uji $\mathbf{R}^{2}$ (R-Square)}

Uji $R^{2}$ (R-Square) digunakan untuk mengukur besaran persentase variabel terikat dapat dijelaskan oleh variabel bebasnya secara simultan dan nilai koefisien determinasi berkisar antara 0 sampai 1. Semakin mendekati angka 1 semakin baik variabel bebasnya dalam menjelaskan variasi perubahan pada variabel terikat. Pada penelitian ini berikut adalah hasil R2 (R-Square) data panel.

Dari tabel dapat dilihat bahwa nilai (R-Square) dari hasil regresi sebesar 0.297068 , artinya $29,71 \%$ hasil investasi perusahaan asuransi jiwa syariah dipengaruhi oleh inflasi, nilai tukar, dan produk domestik bruto. Sedangkan 70,29\% dipengaruhi oleh variabel lainnya yang tidak termasuk di dalam penelitian ini.

\section{SIMPULAN DAN SARAN}

\section{SIMPULAN}

Berdasarkan hasil analisis data dan pembahasan yang telah dijelaskan sebelumnya, maka dapat ditarik kesimpulan, sebagai berikut:

1. Variabel inflasi dan variabel nilai tukar secara parsial tidak berpengaruh signifikan terhadap hasil investasi pada perusahaan asuransi jiwa syariah di Indonesia, sedangkan Produk Domestik Bruto (PDB) berpengaruh signifikan secara parsial terhadap hasil investasi pada perusahaan asuransi jiwa syariah di Indonesia.

2. Variabel inflasi, nilai tukar dan Produk Domestik Bruto secara simultan berpengaruh signifikan terhadap hasil investasi perusahaan asuransi jiwa syariah di Indonesia.

\section{SARAN}

Berdasarkan simpulan tersebut, saran yang disampaikan dalam penelitian ini adalah:

1. Bagi Praktisi

Perusahaan asuransi jiwa syariah sebagai investor sebaiknya tetap memperhatikan informasi-informasi yang terkait dengan perubahan inflasi, nilai tukar dan produk domestik bruto terkini 
sebelum menempatkan dana investasi, investor diharapkan juga mampu memprediksi nilai investasi dari beberapa efek atau sekuritas yang akan diambil, sehingga dapat mengambil kebijakan investasi ketika perekonomian Indonesia mengalami perubahan dengan mengambil langkah diversifikasi resiko yang lebih baik dan teliti lagi guna meminimalisir atau mengurangi tingkat resiko dan memperoleh hasil investasi yang maksimal. Perusahaan yang memiliki investor asing dalam kepemilikan saham terbesarnya sangat dominan memiliki hasil investasi yang besar, namun juga perlu memperhatikan informasi tentang kekuatan nilai tukar rupiah terhadap mata vang negara lain, karena perusahaan tersebut akan mudah labil terhadap perubahan nilai tukar uang.

Pertumbuhan ekenomi dalam pandangan Islam juga dipengaruhi oleh peran infaq, sedekah dan zakat sebagai bentuk pengelolaan harta yang tidak produktif (idle assets). Peningkatan besar zakat yang dikeluarkan akan memberi dampak baik pada ekonomi karena ikut berperan dalam meningkatkan tingkat produktif atau angka kerja pada masyarakat yang membutuhkan, sehingga pemerataan kesejahteraan pada semua kalangan akan tercapai. Oleh karena itu, perusahaan asuransi jiwa syariah seharusnya juga ikut berperan dalam pendistribusian zakat di Indonesia.
2. Bagi Regulator

Bank Indonesia sebagai regulator moneter diharapkan dapat menjaga kestabilan moneter karena dari hasil penelitian ini variabel inflasi, nilai tukar dan Produk Domestik Bruto (PDB) berpengaruh sebesar 29,71 persen sisanya sebesar 70,29 persen dijelaskan oleh variabel yang tidak diteliti. Pemerintah diharapkan dapat mengawasi dan menjaga stabilitas ekonomi agar meminimalisir naiknya harga-harga kebutuhan pokok yang mengakibatkan turunnya minat investor di pasar modal, sehingga akan mempengaruhi hasil investasi perusahaan.

\section{Bagi penelitian selanjutnya}

Penelitian selanjutnya hendaknya memasukkan variabel makro ekonomi lainnya seperti harga saham, tingkat bunga (BI rate), tingkat hutang luar negeri Indonesia dan tingkat pajak yang berlaku. Penggunaan variabel moderating atau intervening, karena ada beberapa variabel yang tidak bisa berpengaruh secara langsung terhadap hasil investasi perusahaan. Obyek penelitian bisa diganti dengan hasil investasi perusahaan asuransi umum syariah dan reasuransi syariah, sehingga dapat mengembangkan penelitian ini mengingat bahwa asuransi syariah adalah salah satu lembaga keuangan syariah yang cukup berpotensi dan turut meningkatkan perekonomian di Indonesia. 
Zein, et al/Jurnal Ekonomi Syariah Teori dan Terapan Vol. 4 No. 10 Oktober 2017: 773-786; KONDISI MAKRO EKONOMI TERHADAP HASIL INVESTASI ASURANSI JIWA SYARIAH DI INDONESIA

\section{DAFTAR PUSTAKA}

Alhasymi, M. 2010. Pengaruh Inflasi, Suku Bunga Riil dan Kurs terhadap Investasi Asing Langsung di Indonesia. Yogyakarta: YKPN

Alquran dan Terjemahannya

Anshori, Abdul Ghofur. 2007. Asuransi Syariah di Indonesia: Regulasi dan Operasionalisasinya di dalam Kerangka Hukum Positif di Indonesia. Yogyakarta: UII Press.

Antonio, Muhammad Syafii, dkk. 2004. The Isamic Capital Market Volatility A Comparataive Study Between In Indonesia and Malaysia. Buletin Ekonomi Moneter dan Perbankan.

Badan Pusat Statistik. 2015. Perkembangan Produk Domestik Bruto di Indonesia

Bank Indonesia. 2015. Perkembangan Inflasi dan Nilai Tukar di Indonesia

Billah, Mohd. Masum. 1998. Islamic Insurance: Its Origins and Development, Arab Law Quarterly, Vol. 13, No. 4 (1998).

Chen, Roll, dan Ross. 1986 Chen, R. \& Wong, K. A. 2004. The Determinants of Financial Health of Asian Insurance Companies. Journal of Risk and Insurance, 71: 469-499

Fahmi, Irham. 2012. Manajemen Investasi. Jakarta: Salemba empat

Gujarati, Damodar. 2013. Ekonometrika Dasar Buku 2. New York: The McGraw-Hill Companies, Inc.

Huda, Nurul dan Mustafa Nasution Edwin. 2008. Investasi pada Pasar Modal Syariah. Jakarta: Kencana
Karim, Adiwarman. 2001. Ekonomi Islam Suatu Kajian Ekonomi Makro. Jakarta:IIIT Indonesia

Karim, Adiwarman. 2007. Bank Islam: Analisis Fiqih dan Keuangan Edisi Ketiga. Jakarta: PT Raja Grafindo Persada

Keputusan Menteri Keuangan RI No. 424/KMK.06/2003 tentang Kesehatan Keuangan Perusahaan Asuransi dan Perusahaan Reasuransi.

Majalah Ekonomi. 2015. No. 178. Tahun LVII (Desember).

Mankiw, Gregory. 2005. Pengantar Ekonomi Makro, Edisi Ketiga, Jakarta: Salemba Empat

Metwally, M.M. 1995. Teori dan Model Ekonomi Islam. Jakarta: PT. Bangkit Daya Insana

Nopirin. 1997. Ekonomi Moneter Buku Dua. Yogyakarta: BPFE

Otoritas Jasa Keuangan. 2015. Investasi Terbesar yag Menjadi Pilihan Perusahaan Asuransi Jiwa Syariah

Pilbeam, Keith. 2006. International Finance 3rd Edition. New York.

Putang, Iskandar. 2002. Ekonomi Mikro dan Makro. Jakarta: Ghalia Indonesia

Republik Indonesia. Peraturan Menteri Keuangan Nomor 11/PMK.010/2011 tentang Kesehatan Kevangan Usaha Asuransi dan Usaha Reasuransi Dengan Prinsip Syariah.

Soedibyo, Sugeng dan Rachma Fitriati. 2009. Penetapan Target Premi Asuransi Jiwa Syariah Untuk Mencapai Titik Impas dengan Pendekatan Model Profit Testing. 
Jurnal Ilmu Administrasi dan Birokrasi,

Vol. 16, No. 2:59-67

Soegiyono. 2003. Metode Penelitian

Pendidikan (Pendketan Kualitatif,

Kualitatif dan R\&D). Bandung:

Alfabeta

Statistik Perasuransian Syariah, Asosiasi

Asuransi Syariah Indonesia

Sukirno, Sadono. 2002. Makroekonomi Modern. Jakarta: PT Raja Grafindo

Sula, Muhammad Syakir. 2004. Asuransi Syariah (Life and General): Konsep dan Sistem Operasional, Cetakan I Jakarta: Gema Insani Press

Suta, I Putu Gede Ary. 2000. Menuju Pasar Modal Modern. Yayasan SAD Satria Bhakti, Jakarta.

Tolefat, Abdulrahman Khalil dan Mehmet Asutay. 2013. Takaful Investment Portofolios: A Study of The Somposition of Takaful Funds in The GCC and Malaysia. Singapore: John Wiley \& Sons Singapore Pte. Ltd.

Zuhra, Amalia N. 2015. Pengaruh Variabel Makroekonomi Terhadap Jakarta Islamic Index (JII) Periode 2006-2014, Fakultas Ekonomi dan Bisnis. Universitas Airlangga 